\title{
ДВИЖЕНИЕ СОЛИДАРНОСТИ С НАРОДАМИ АЗИИ И АФРИКИ В КАЗАХСТАНЕ
}

\section{MOVEMENT OF SOLIDARITY WITH THE PEOPLES OF ASIA AND AFRICA IN KAZAKHSTAN}

\section{S. Azerbayev}

Summary: In the article, the author draws attention to how the solidarity movement in support of the struggle of African peoples against colonial oppression was born in Kazakhstan during the Soviet period. The article shows the activities of the Republican Committee of solidarity of Asian and African countries, which contributed to the development of cultural relations with the States of the Black continent. With the independence of Kazakhstan, the desire for active political, cultural and economic cooperation of the Republic with the States of Africa was expressed.

Keywords: Kazakhstan, Africa, solidarity, cooperation, culture.
Азербаев Салават Губайдуллович

К.и.н., профессор, Казахский университет международных отношений и мировых языков имени Абылай хана,

Алматы, Казахстан salavat_azersmir@mail.ru

Аннотация: В статье автор обращает внимание на то, как в советское время зарождалось в Казахстане движение солидарности в поддержку борьбы африканских народов против колониального гнета. Показана деятельность республиканского Комитета солидарности стран Азии и Африки, которое способствовало развитию культурных отношений с государствами Черного континента. С обретением Казахстаном независимости выражено стремление к активному политическому и культурно-экономическому сотрудничеству республику с государствами Африки.

Ключевые слова: Казахстан, Африка, солидарность, сотрудничество, культуpa.

лизма, неоколониализма, расизма, сионизма и фашизма, за обеспечение их экономического, социального и культурного развития. Штаб-квартира — в Каире. было время, когда после окончания 2 мировой войны по всему миру стала активно шириться движение за освобождение от колониализма в странах Азии и Африки. К тому времени еще большинство африканских государств находилось в колониальной зависимости, и борьба за освобождение принимало все более ожесточенный характер. Действенным толчком к антиколониальной борьбе за свободу и независимость стала прошедшая в Индонезии международная конференция в Бандунге в 1955 году.

Результатом конференции стало создание единого фронта народов Азии и Африки. Согласованной платформой конференции стал антиимпериализм и антиколониализм.

Принятые на конференции решения имели огромное значение для укрепления взаимопонимания между народами и странами Азии и Африки, для развития национально-освободительной борьбы угнетенных народов против колониализма, для мира и безопасности [1,с.113].

Через два года в Каире 26 декабря 1957 г. - 1 января 1958 г. состоялась 1-я конференции солидарности стран Азии и Африки под названием Совет солидарности стран Азии и Африки. Это международная общественная организация, ставящая своей задачей объединение, координацию и усиление освободительной борьбы народов Азии и Африки против империализма, колониа-
Советская сторона, придавая высокое значение учредительной конференции направило парламентскую делегацию во главе с Шарафом Рашидовым, в то время он являлся председателем Президиума Верховного Совета Узбекской ССР, заместителем председателя Президиума Верховного Совета СССР. В составе делегации были представители из Туркменистана, Таджикистана, Узбекистана и Казахстана. Из Казахстана были - министр социального обеспечения республики, депутат Верховного Совета Казахской ССР Балжан Бультрикова и Нурмолда Алдабергенов, председатель колхоза им. Сталина Талды-Курганского района Алма-Атинской области, депутат Верховного Совета СССР, дважды Герой социалистического труда. По возвращении из Каира они выступали перед общественностью республики о работе конференции. Так, на страницах республиканской газеты «Казахстанская правда» 19 января 1958 года Н. Алдабергенов опубликовал статью «Свет над Каиром», где поделился своими впечатлениями об итогах конференции и встречах с египтянами.

Как известно, национально-освободительное движение угнетенных народов обрело бурный характер после окончания 2-й Мировой войны и стало активно развиваться в конце 50-х годов. В 60-е годы оно поднялось на качественно новую ступень. Вооруженная борьба во многих странах шла параллельно с постановкой и ча- 
стичным решением задач социального освобождения колониальных народов. В процессе освободительной борьбы готовились глубокие социально-экономические преобразования: аграрные реформы, преобразования в области просвещения, здравоохранения и т.д. Отдельные очаги борьбы в странах Азии, Африки и Латинской Америки, а позднее и Океании превратились в мировое национально-освободительное движение, которое стало составной частью мирового революционного процесса.

Советская общественность горячо поддержало эту борьбу.

В Советском Союзе Движение солидарности с народами Азии и Африки началось в 1956 году, которое постепенно распространилось на все республики Средней Азии, Закавказья и Казахстан. Впоследствии там были созданы республиканские Комитеты солидарности. Этому способствовало принятое Постановление Президиума Советского Комитета Солидарности стран Азии и Африки от 20 февраля 1961 года «О создании в союзных республиках азиатской части СССР республиканских комитетов солидарности стран Азии и Африки».

В этом документе говорилось: «За последние годы значительно расширились связи советской общественности с народами стран Азии и Африки, увеличился обмен делегациями между Советским Комитетом Солидарности и национальными комитетами солидарности в странах Азии и Африки, что в свою очередь способствует дальнейшему повышению активности народов Азии и Африки в борьбе с империализмом, за мир, разоружение и окончательной ликвидации колониализма.

Трудящиеся республик азиатской части СССР, принимая активное участие в поддержке национально-освободительной борьбы в колониальных и зависимых странах, проявляют инициативу и выступают с предложениями о дальнейшем расширении связей и контактов общественных организаций Советского Союза с общественностью стран Азии и Африки.

Президиум Советского Комитета солидарности поддерживает эту инициативу и считает целесообразным создание республиканских комитетов солидарности стран Азии и Африки в Азербайджанской, Армянской, Грузинской, Казахской, Киргизской, Таджикской, Туркменской и Узбекской ССР на общественных началах.

Президиум считает, что основными задачами республиканских комитетов солидарности являются:

- активное участие во всех мероприятиях, направленных на поддержку борьбы колониальных и зависимых народов Африки и Азии за свободу и национальную независимость, против империа- лизма, колониализма, за мир и разоружение;

- дальнейшее расширение связей с народами стран Азии и Африки;

- широкое ознакомление общественности афроазиатских стран с опытом и достижениями советского народа в коммунистическом строительстве, в развитии экономики, науки и культуры.

Республиканские Комитеты солидарности проводят свою работу в тесном контакте с соответствующими республиканскими общественными организациями и Советским Комитетом Солидарности стран Азии и Африки» $[2]$.

Этот документ лег в основу принятия Постановления ЦК КПСС “О создании в республиках Средней Азии и Закавказья республиканских комитетов Солидарности Стран Азии и Африки", которое было разослано всем упомянутым республиканским партийным организациям. В каждой из этих республик были приняты свои партийные решения по данному вопросу. В Казахской ССР он обсуждался в секретариате ЦК Компартии Казахстана, которое приняло Постановление от 7 марта 1961 года, утвержденное на Бюро ЦК Компартии Казахстана 31 марта 1961 года о создании в Казахстане республиканского Комитета Солидарности Стран Азии и Африки на общественной основе. В нем, в частности, отмечалось:

«Для организационного оформления комитета созвать конференцию представителей общественности республики 23 марта 1961 г.

Утвердить количество делегатов республиканской конференции 100 чел.

Докладчиком на конференции по вопросу “Народы Азии и Африки в борьбе против колониализма и задачи Казахского Комитета Солидарности Стран Азии и Африки" рекомендовать т. Ауэзова М.О.

Поручить Казахскому республиканскому Комитету Солидарности Стран Азии и Африки в отдельных случаях осуществлять обмен делегациями со странами Азии и Африки в пределах средств, выделяемых на эти цели» [3].

Постановление ЦК Компартии Казахстана было принято, как руководство к действию и 23 марта в Алма-Ате состоялась учредительная конференция по созданию Казахского Республиканского Комитета солидарности стран Азии и Африки. В ходе конференции и докладчик и все выступавшие говорили о своей солидарности с народами Африки в их борьбе против колониализма, за свободу и независимость, единодушно одобряли и поддерживали решение о создании в Казахстане Комитета солидарности стран Азии и Африки. Так, в своем высту- 
плении писатель С. Мауленов отметил, что в Казахстане в 1959 году был издан большой сборник стихов поэтов Азии и Африки, который стал одним из любимых книг казахстанских читателей. Приветствуя участников конференции, он подчеркнул: «Мы - писатели Казахстана, горячо поддерживаем создание у нас в республике Комитета солидарности стран Азии и Африки. Мы своим пером и искусством активно будем служить делу мира, делу солидарности и единства азио-африканских народов». Закончил свое выступление стихами на казахском языке, посвященные народам Азии и Африки [4].

Был избрано Правление в количестве 29 человек. Среди них были деятели науки, культуры, представители колхозного крестьянства, передовики производства. Н. Алдабергенов - председатель колхоза им. Сталина Талды-Курганского р-на Алма-Атинской области, депутат Верховного Совета СССР, дважды Герой Социалистического труда, Х. Арыстанбеков - министр сельского хозяйства, М.О. Ауэзов- писатель, лауреат Ленинской и Госпремии, депутат ВС КазССР, К. Ахметов - председатель Совета Союза спортивных обществ и организаций Казахстана, Н.У. Базанова - академик, председатель Казахского Комитета защиты мира, Н.И Петрушин- секретарь ЦК ЛКСМ Казахстана,

А. Бисенова - директор института материнства и детства, А.С. Шандрина - директор Алма-Атинской швейной фабрики, Л.Г. Галимжанова - министр культуры и другие. Первым председателем республиканского Комитета солидарности стран Азии и Африки был избран писатель М.О. Ауэзов [5].

После учреждения республиканского Комитета солидарности стран Азии и Африки в республике стали ежегодно повсеместно проводиться мероприятия в поддержку борьбы африканских народов против колониализма. Так, под лозунгом солидарности с народами Африки, борющимися за свое освобождение и национальное развитие, прошло19 апреля 1961 г. в г. Чимкенте, посвященное Дню свободы Африки.

Согласно решению Исполкома организации солидарности с народами Азии и Африки в Алма-Ате с 17 по 24 января 1962 г. была проведена Неделя солидарности с народами Конго.

Около 400 рабочих, служащих завода тяжелого машиностроения в своей резолюции заявили "Знамя освобождения всей Африки подняли тысячи крепких рук новых борцов. Мы верим, сбудутся слова Патриса Лумумбы "Африка напишет свою собственную историю и это будет на севере и юге Африки - история славы и достоинства".

24 января 1962 г. на общегородском собрании представителей общественности Алма-Аты в республикан- ском театре драмы присутствовало около 1000 человек. С докладом "Идеи Лумумбы победят" выступила солистка оперного театра, народная артистка СССР Р.У. Джаманова. В своих выступлениях рабочий завода низковольтной аппаратуры А.Г. Меркушев, директор Института философии и права АН КазССР, доктор юридических наук С.З. Зиманов и другие выразили свою солидарность с патриотами Конго в их благородной борьбе за единство и независимость, с возмущением говорили о том, что жизнь последователя и соратника П. Лумумбы А. Гизенги в опасности и требовали положить конец произволу, творимые над многострадальным народом Конго.

В Резолюции собрания общественности Алма-Аты говорилось: "Мы решительно требуем, как можно скорее, предотвратить новое империалистическое преступление в Конго! Мы считаем, что грязной игре империалистических кругов в Конго должен быть положен конец!"[6].

Собрания, посвященные этой Неделе, были проведены в Алма-Атинском головном приборо-ремонтном заводе, табачном комбинате, мелькомбинате, типографии № 2, Министерстве геологии, мебельной фабрике, медицинском институте и т.д. [7].

В последующие годы в Казахстане общественность республики постоянно выступала в защиту народов Африки, ведущих борьбу против неколониализма. Так, в 1972 году по случаю Дня независимости Зимбабве, член Президиума Казахского комитета солидарности Стран Азии и Африки, ректор Института физкультуры К.Г. Ахметов выступил по казахскому радио с беседой на тему: "Национально- освободительное движение народов Юга Африки".

В связи с 12-й годовщиной расправы властями ЮжноАфриканского городка Шарпевиль над мирными демонстрантами в Алма-Ате в 1972 году эту дату отметили, как Международный день борьбы за ликвидацию расовой дискриминации. Казахская телестудия посвятила специальную передачу с показом фотоматериалов Африканского конгресса Южной Африки, полученные из Советского Комитета Солидарности.

Казахстанцы, как и все советские люди, вместе с мировой общественностью сурово осудили убийство выдающегося деятеля африканского освободительного движения, Генерального секретаря Африканской Партии независимости Гвинеи и о-вом Зеленого Мыса (ПАИГК) Амилкара Кабрала. ККССАА совместно с Казахским обществом дружбы была направлена телеграмма соболезнования в Конакри [8].

В работе в январе-феврале 1963 года в городе Моши (Танганьика) Ш-й конференции солидарности народов 
Азии и Африки участвовала делегация Советского Комитета Солидарности стран Азии и Африки во главе с его председателем, депутатом Верховного Совета СССР, таджикским писателем Мирзо Турсун-заде. В составе делегации был секретарь ЦК КП Казахстана Нурумбек Джандильдин [9].

В Казахстане придали высокое значение этому международному событию. 22 марта 1963 г. было проведено собрание представителей общественности г. Алма-Аты, посвященной итогам Ш Конференции солидарности народов Азии и Африки, на котором с докладом выступил секретарь ЦК КП Казахстана Н. Джандильдин. В своем выступлении докладчик остановился на экономических связях Казахстана со странами Африки и Азии и их перспективах. В: “Большую техническую помощь африканским странам в проведении геологоразведочных работ оказывают казахстанские геологи. В настоящее время они успешно работают, передавая свой опыт в Гане, Мали, ОАР, Индии, Афганистане, Монголии и других странах» [10].

В республике по линии Казахского комитета солидарности стали активно проводиться различные международные конференции и симпозиумы с участием африканских делегаций. Самым знаменательным событием стало проведение в октябре 1969 года международного симпозиума на тему «Ленинское учение о национально-освободительных революциях и современный этап социального прогресса развивающихся стран». В его работе приняли участие представители стран социалистического содружества, а также из Латинской Америки, Азии и Африки. Тогда в Алма-Ату впервые приезжал генеральный секретарь Организации солидарности народов Азии и Африки египетский писатель Юсеф эс-Сибаи.

Надо особо отметить, что Движение солидарности с народами Азии и Африки было подхвачено писателями двух континентов. В октябре 1958 года в Ташкенте состоялась писательская конференция стран Азии и Африки. В ее работе приняли участие и казахстанские писатели М. Ауэзов, Г. Мусрепов, А. Тажибаев, М. Каратаев, 3. Кабдолов, М. Сармурзина [11].

Творческие связи деятелей литературы двух континентов стали с годами шириться и развиваться. Если на Ташкентской конференции собрались представители чуть более 40 стран, то 15 лет спустя на V Алма-Атинской конференции в сентябре 1973 года собрались представители уже 4 континентов - из 55 стран Азии и Африки и 13 стран Европы, США, и Латинской Америки, представители ряда международных общественных организаций.

В подготовке и проведению конференции наряду с писательскими организациями активное участие принимало Движение солидарности стран Азии и Африки,
СКССАА и комитеты солидарности республик Средней Азии, Закавказья и Казахстана. На открытии выступили Мирзо Турсун-заде и Юсеф эс-Сибаи.

Участникам конференции было зачитано приветствие Генерального секретаря ЦК КПСС Л. Брежнева, в котором он подчеркнул «Советские люди неизменно солидарны со свободолюбивой борьбой народов Азии и Африки против империализма, колониального и расистского гнета... Мы неизменно поддерживаем борьбу народов Африки за ликвидацию колониальных и расистских режимов... Пусть она [конференция] войдет в историю писательского движения афро-азиатских стран как важная веха в упрочении братского содружества деятелей культуры, чье призвание - отстаивать мир, оберегать и развивать достижения цивилизации для своих современников, для грядущих поколений!» [12].

В ходе работы писательского форума, в целом, отмечались единство взглядов на важнейшие проблемы мира, понимание роли писателя в обществе, в борьбе против империализма, неоколониализма и сионизма, за мир и прогресс. На ней состоялся широкий обмен мнениями о задачах литературы 2-х континентов в борьбе за мир, демократию и социальный прогресс. В резолюциях, принятых культурными комитетами конференции, содержался призыв писателей ко всем художникам слова разоблачать реакционную идеологию неоколониализма, бороться против проникновения этой идеологии в культурную жизнь стран Азии и Африки, активно участвовать в жизни народов, в антиимпериалистической борьбе, содействовать взаимообогащению прогрессивных культур Востока и Запада [13].

Активность казахстанско-африканских литературных связей дала определенные успехи. Единение писательской братии дало определенный стимул в борьбе народов двух континентов против происков империализма и неоколониализма. Высоко оценивая вклад казахстанских писателей в это движение, в 1985 году писатель Ануар Алимжанов, член Правления КKССАА, был первым казахстанцем удостоенный международной африканской премией по литературе имени президента Анголы Агостиньо Нето.

Другим важным мероприятием в деятельности Казахского Комитета солидарности стран Азии и Африки явилось участие в подготовке и проведении в Алма-Ате с 27 мая по 1 июня 1979 г. Международного семинара “Роль общественности в поддержке борьбы народов Юга Африки против расизма, апартеида и неоколониализма".

Семинар был организован СККАА и Институтом Африки АН СССР в сотрудничестве со специальным комитетом ООН против апартеида. В его работе приняли участие представители общественности 36 стран, многих 
международных организаций и национально-освободительных движений, видные советские и зарубежные ученые, общественные деятели. С докладом “СССР и борьба за освобождение Юга Африки" выступил директор института Африки АН СССР, профессор Ан. А. Громыко [14].

Общественность Казахстана активно выражала свое отношение к справедливой борьбе африканских народов за свои права. В 1982 г. в республике с участием Казахского отделения Советской Ассоциации дружбы с народами Африки и республиканского Комитета солидарности стран Азии и Африки широко отмечались даты - 70-летие создания АНК Южной Африки, День освобождения Африки и Неделя солидарности с борьбой народов Юга Африки, годовщина провозглашения НР Ангола и др.

Так, 8 января 1982 г. в Алма-Ате, Доме Дружбы, состоялось торжественное собрание по случаю 70-летия создания АНК Южной Африки. Были проведены митинги и собрания, лекции, беседы, посвященные Дню освобождения Африки и Неделе солидарности на Алма-Атинском электромеханическом заводе, на биокомбинате АлмаАты, Кокчетавском заводе кислородно-дыхательной аппаратуры и других предприятиях. Были организованы выступления членов комитета по республиканскому Радио в цикле "Дружба - великая сила", в Государственной библиотеке им Пушкина - книжно-журнальная выставка, в Доме Дружбы - фотовыставка "Советская общественность в поддержке борьбы народов Юга Африки и книжно-журнальная выставка "Африка сегодня" [15].

Движение солидарности с народами Азии и Африки в Казахстане носило широкомасштабный характер. В нем принимали активное участие широкие слои населения, начиная от рабочего и колхозника и кончая учеными и министрами. В республику приезжали многочисленные африканские делегации, которые знакомились с советской действительностью. Они старались узнать как можно больше о том, как в стране развивается экономика, наука, культура, искусство. Их интересовали вопросы образования и медицинского обслуживания, развитие инфраструктуры городов, забота о детях, положение женщины в обществе.

Так, в августе 1966 г. в Алма-Ате по приглашению CКССАА находилась делегация Национального комитета Конголезской ассоциации дружбы между народами во главе с заместителем секретаря ассоциации Дени Бабинги. Гости посетили пионерлагерь "Юный дорожник", ВДНХ, Госпиталь инвалидов войны, музей писателя М. Ауэзова, детский комбинат № 204, киностудию «Казахфильм».

На встрече с председателем ККССАА, секретарем Президиума Верховного Совета Казахской ССР Б. Рамаза- новой Д. Бабинги отметил: “Опыт Казахстана в подъеме экономики и культуры поможет нам в строительстве новой жизни. Нас особенно поразила забота о детях. Такая система организации детских учреждений, забота о детях помогает высвободить большое количество женщин для общественно-полезного труда. Огромных успехов добился Казахстан и в организации народного просвещения. Этот опыт нам тоже полезен» [16].

В сентябре 1966 г. в Алма-Ате гостила делегация Малийского комитета солидарности во главе с председателем Малийского комитета солидарности, Национального Комитета защиты мира, членом Всемирного Совета мира Соу Абдуллайем. В своем выступлении по ТВ он сказал: “ Цель нашего визита - укрепить дружественные связи во имя мира и прогресса. Наша борьба будет усиливаться, и мы построим светлое общество на земле без расовой дискриминации" [17].

В Алма-Ате в апреле 1967 г. была принята делегация партии "Популярная идея Экваториальной Гвинеи" в лице президента партии Иэсуса Мба Овоно и главного представителя этой партии в ОАР Даниэля Гаофу Мбандемежо. На приеме у секретаря Президиума ВС Казахской ССР, председателя ККССАА Б. Рамазановой глава делегации сказал: “Роль женщины в Вашей стране и, в частности, в Вашей республике, удивляет и изумляет нас. А у нас страна все еще остается колониальной. Страна наша очень богатая. У нас много природных богатств как кофе, какао и другие минеральные ресурсы. Но наша страна стала бы еще богаче без испанских колонизаторов. Виной этого безрадостного положения является колониализм. Наши усилия направлены на то, чтобы ликвидировать то искусственно созданное государство, которое никого не представляет. Мы вынуждены работать в Конго (Браззавиль), т.к. автономное государство не терпит нас. Мотив нашей борьбы - получить национальную независимость" [18]. Через год эта страна провозгласила независимость.

В свою очередь и активисты ККССАА выезжали в африканские страны для установления дружественных отношений с родственными общественными организациями. Будучи министром иностранных дел Казахской ССР, впоследствии посол СССР в Мали и Марокко М.С. Фазылов выезжал в Мозамбик в 1975 г. во главе всесоюзной делегации накануне празднования 13-й годовщины создания Фронта освобождения Мозамбика (ФРЕЛИМО). А в следующем году он во главе такой же делегации выезжал в Эфиопию [19].

По приглашению Малийского комитета солидарности народов Азии и Африки в Бамако в июне 1976 г. находилась делегация СКССАА во главе с заместителем председателя Казахского комитета солидарности Г.М. Мурзагалиевым. В опубликованном в Бамако совмест- 
ном коммюнике говорилось, что в ходе визита состоялся обмен мнениями по вопросам борьбы за мир во всем мире, за укрепление солидарности антиимпериалистических сил. Была выражена глубокая признательность советскому народу за бескорыстную помощь молодым независимым государствам Африки и Азии в развитии их национальной экономики. Кроме Республики Мали, представители Советского комитета солидарности стран Азии и Африки посетили Верхнюю Вольту, где были приняты президентом Сангуле Ламизаной [20].

Кроме М.С. Фазылова и Г. Мурзагалиева в составе делегаций Советского Комитета солидарности стран Азии и Африки выезжали - председатель Казахского Комитета солидарности стран Азии и Африки, секретарь Президиума Верховного Совета Казахской ССР Х. Х. Демесинов в Руанду. А в Эфиопию по линии Комитета солидарности выезжал министр иностранных дел республики М.И. Исиналиев [21].

Из сказанного видно, что в советский период времени Казахстан имел достаточно конкретные и разносторонние связи с африканскими странами по линии Советского Комитета солидарности стран Азии и Африки. Однако конец XX века знаменовал в мире драматическое событие - распад Советского Союза, что повлекло за собой прекращение в союзных республиках функционирование национальных комитетов солидарности. Но к этому времени в Азии и Африке уже не осталось ни одной страны под колониальным гнетом. Следовательно, в целом, Советский Комитет солидарности стран Азии и Африки выполнил свою основную задачу - оказал действенную поддержку в деле обретения этими странами национальной независимости. Но с другой стороны для государств Черного континента он обернулся практически полной экономической, а как следствие политической зависимостью африканских государств от стран Запада и вступающего с ним в конкуренцию «нового ак- тора» в лице KHP.

В настоящее время независимый Казахстан восстанавливает утраченные связи с государствами Африки. Накопленный в советское время опыт сотрудничества с африканскими странами, в настоящее время помогает республике предпринимать шаги по развитию отношений с ними на новой ступени. В отличие от советского периода отношения стали строиться не столько по линии общественных организаций, сколько на конкретных торгово-экономических и дипломатических связях. Суверенный Казахстан признан почти всеми государствами Африки. С тремя странами Африки - Египет, Эфиопия и ЮАР - Казахстан осуществил взаимное открытие дипломатических представительств на уровне посольств.

Суверенный Казахстан на международной арене активно поддерживает африканские страны в рамках деятельности международных организаций - во время председательства в Организации исламского сотрудничества (2011-2012 гг.) и во время работы в качестве непостоянного члена Совета Безопасности ООН (2017-2018 гг.).

В разное время Казахстан посетили президенты Египта, Сенегала, Руанды и других стран. Первый президент Республики Казахстан Н. Назарбаев посетил Египет и ЮАР. Нынешний глава государства К-Ж. Токаев, будучи министром иностранных дел РК, также выезжал в Египет, Марокко и ЮАР. В результате этих поездок стали заключаться взаимовыгодные культурно-экономические отношения между Казахстаном и этими странами. Такая форма сотрудничества должна привнести новый импульс во взаимоотношениях между африканскими государствами и суверенным Казахстаном, что, несомненно, должно стать новой страницей в деле развития взаимовыгодных торгово-экономических и культурных связей, направленные на укрепление дружественных отношений Казахстана и Африки.

1. Дипломатический словарь. Т. 1. М.: Наука, 1985. С. 113.

ЛИТЕРАТУРА

2. Центральный Госархив РК, Ф. 1808, оп. 1, д. № 16, л. 4-5.

3. Архив Президента РК, Ф. 708, оп. 34, д. № 122, л. 264- 265.

4. Центральный Госархив РК, Ф. 1808, оп. 1, д. № 161, л. 65.

5. Центральный Госархив РК, Ф. 1808, оп. 1, д. № 161, л. 49.

6. Центральный Госархив РК, Ф. 1808, оп. 1, д. № 203, л. 11-12.

7. Центральный Госархив РК, Ф. 1808, оп. 1, д. № 183, л. 42.

8. Архив Президента РК, Ф. 708, 0п. 56, л. 54-57.

9. Крепить солидарность народов Азии и Африки, ТАСС // Казахстанская правда, 30.01.1963.

10. Центральный Госархив РК, Ф. 1808, оп. 1, д. № 215, л. 19.

11. Литература должна служить делу мира // Казахстанская правда, 10.10.1958.

12. Приветственное послание Генерального секретаря ЦК КПСС Л.И. Брежнева // Казахстанская правда, 05.09.1973. 
13. Архив Президента РК, Ф. 708, оп. 56, д. № 162, л. 194-195.

14. Архив Президента РК, Ф. 708, оп. 91, д. № 198, л. 11-12.

15. Архив Президента РК, Ф. 708, оп. 103, д. № 111, л. 40-41.

16. Центральный Госархив РК, Ф. 1808,0п. 1, д. № 280, л. 109-111.

17. Центральный Госархив РК, Ф. 1808, оп. 1, Д. № 280, л. 148.

18. Центральный Госархив РК, Ф. 1808, оп. 1, д. № 309, л. $22-23$.

19. Азербаев С. Служение Отечеству: Книга о дипломате М.С. Фазылове: научное исследование, очерки, воспоминания, документы. Алматы: Жибек жолы, 2010. 472 c.

20. Визит советской делегации, ТАСС // Правда, 15.06.1976.

21. Центральный Госархив РК, Ф. 1955, оп. 2, д. 466, л. 17.

(c) Азербаев Салават Губайдуллович (salavat_azersmir@mail.ru).

Журнал «Современная наука: актуальные проблемы теории и практики»

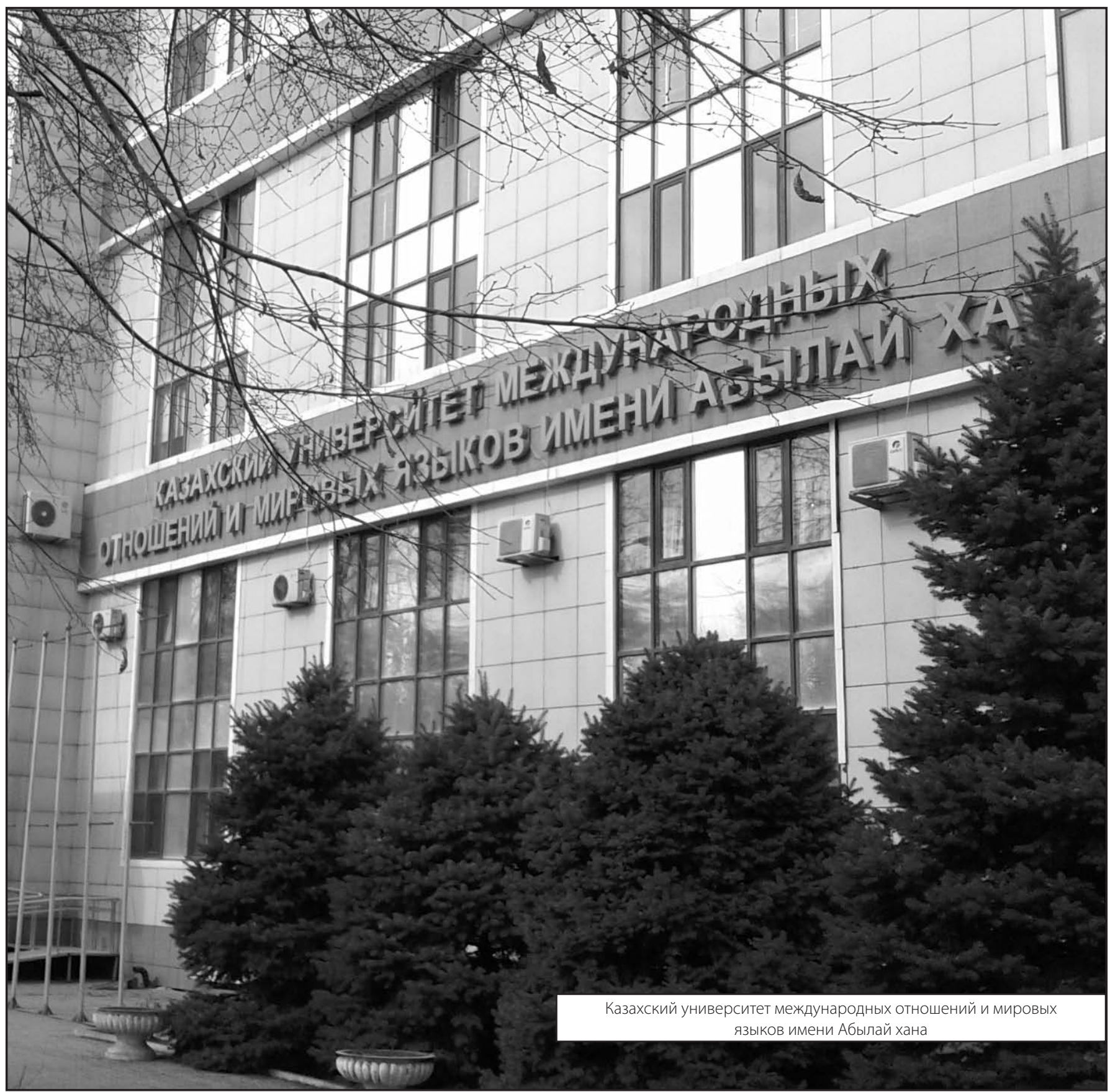

